\title{
The Electrochemical Behavior of the NiTi Alloy in Different Simulated Body Fluids
}

\author{
Alana Witt Hansen ${ }^{a *}$, Luciane Taís Führ ${ }^{b}$, Leonardo Marasca Antonini ${ }^{a}$, \\ Denis Jardim Villarinho ${ }^{b}$, Cláudia Eliana Bruno Marino ${ }^{c}$, Célia de Fraga Malfatti ${ }^{a}$ \\ ${ }^{a}$ Corrosion Research Laboratory - LAPEC, Federal University of Rio Grande do Sul - UFRGS, \\ 9500 Bento Gonçalves avenue, Porto Alegre, RS, Brazil \\ ${ }^{b}$ Exact and Technology Sciences Institute - ICET, Feevale University, \\ 2755 ERS-239, Novo Hamburgo, RS, Brazil \\ 'Mechanical Engineering Department, Federal University of Paraná - UFPR, \\ 1299 XV de Novembro street, Curitiba, PR, Brazil
}

Received: June 26, 2014; Revised: February 3, 2015

\begin{abstract}
In order to improve the NiTi alloy biocompatibility, surface treatments become very important. Nevertheless, researchers use different solutions to simulate the body fluids in electrochemical assays, and the correlation between the obtained results is difficult and might not even be possible. The present paper evaluated the electrochemical behavior of polished NiTi surfaces exposed to different simulated body fluid solutions: Hanks solution, Hanks' balanced salt (HBSS) solution, saline body fluid (SBF) solution, and Ringer solution. The electrochemical behavior of NiTi was evaluated by open circuit potential (OCP) and cyclic voltammetry tests. The surfaces of the samples were also characterized by scanning electron microscopy, which was performed after the electrochemical tests. The results demonstrated that the NiTi alloy shows the same corrosion mechanism (pitting) in all simulated body fluids that were studied. However, the corrosion potential changes for each electrolyte, being HBSS, SBF and Ringer the most corrosive solutions. Furthermore, the Hanks and HBSS solutions demonstrated good reproducibility of the electochemical results. Considering that the HBSS represents an extreme environment, this solution seems to be the most indicated to study the corrosion behavior of NiTi treated surfaces.
\end{abstract}

Keywords: metallic biomaterial, electrochemical behavior, NiTi, simulated body fluids

\section{Introduction}

The NiTi alloy is extensively used in the biomedical field due to its notable mechanical properties of superelasticity and shape memory ${ }^{1}$. Comparative studies of biocompatibility between alloys ${ }^{2}$ show that the solubilized nickel may present several adverse reactions. Despite the reports of some authors ${ }^{3,4}$ of the lack of cytotoxicity of alloys, a study conducted by Fili $^{5}$ found that Ni-rich precipitates in NiTi osseous implants chemically passivized with $\mathrm{HF}$, $\mathrm{HNO}_{3}$ and $\mathrm{H}_{2} \mathrm{O} 300$ days after implantation. A number of methodologies were proposed with the objective of creating a barrier that would block the release of nickel, resulting in an increased biocompatibility of the alloy and corrosion resistance: anodization ${ }^{6,7}$, heat treatments for superficial oxidation ${ }^{8,9}$, sputtering ${ }^{10,11}$, plasma electrolytic oxidation $^{12}$, plasma immersion ion implantation ${ }^{13}$, hydroxiapatite/zirconia composite coating ${ }^{14}$, TiN coating ${ }^{15}$, sol-gel technology ${ }^{16}$ metal vapor vaccum arc plasma source $^{17}$. The correlation of the results from these studies in regards to the corrosion resistance is complex due to the different simulated body fluids that were used as electrolytes. The American Society for Testing and Materials (ASTM)

*e-mail: alanawitt@hotmail.com standard to determine the corrosion susceptibility of small implant devices does not specify the electrolyte formulation - only an ion concentration range is mentioned ${ }^{18}$. However, the different electrolyte compositions may result in distinct aggressiveness and corrosion mechanisms. Some of the most used solutions to simulate body fluids include: Ringer's solution $^{19}$, Hanks solution ${ }^{20,21}$, Hanks balanced salt solution $(\mathrm{HBSS})^{22}$, saline body fluid solution $(\mathrm{SBF})^{23}$.

A study of Qiu et al. ${ }^{14}$ used mechanically polished and hydroxiapatite/zirconia $\left(\mathrm{HAP} / \mathrm{ZrO}_{2}\right)$ electrodeposited NiTi. The electrochemical corrosion test was performed in an SBF solution. These authors observed a corrosion current density $\left(i_{\text {corr }}\right)$ of $3.98 \times 10^{-7} \mathrm{~A} / \mathrm{cm}^{2}$ for the NiTi uncoated sample, and of $7.00 \times 10^{-9} \mathrm{~A} / \mathrm{cm}^{2}$ for the $\mathrm{HAP} / \mathrm{ZrO}_{2}$ coated sample, which is almost 60 times lower ${ }^{14}$. They also found that the breakdown potential $\left(\mathrm{E}_{\mathrm{br}}\right)$ of the bare NiTi sample appeared at nearly $600 \mathrm{mV}$, while coated samples did not break at studied potentials ${ }^{14}$. Zhao et al. ${ }^{17}$, on the other hand, used a commercial NiTi polished alloy samples, as well as samples polished by metal vapor vaccum arc plasma (MEVVA 100) with different parameters. The electrochemical tests were conducted in Hank's solution. 
Nb-NiTi samples exhibit much higher $\mathrm{E}_{\text {corr }}(-396 \mathrm{mV})$ and $\mathrm{E}_{\mathrm{br}}(1094 \mathrm{mV})$ than the untreated NiTi samples $\left(\mathrm{E}_{\text {corr }}=-478 \mathrm{mV}, \mathrm{E}_{\mathrm{br}}=420 \mathrm{mV}\right)$. The authors state that $\mathrm{E}_{\mathrm{br}}$ is an indication to evaluate the susceptibility to pitting corrosion, thus, higher $\mathrm{E}_{\mathrm{br}}$ values means higher resistance to pitting corrosion ${ }^{17}$. They also found that the $i_{\text {corr }}$ values of the Nb-NiTi samples $\left(5.89 \times 10^{-10} \mathrm{~A} / \mathrm{cm}^{2}\right)$ were much lower than that of the untreated NiTi $\left(1.07 \times 10^{-8} \mathrm{~A} / \mathrm{cm}^{2}\right)$, suggesting a much slower eroding rate. In both studies, the developed surface treatment improved the corrosion resistance of the NiTi. Even though the $\mathrm{Nb}$ alloy treatments developed lower current densities, it is important to notice that the corrosion densities found by Zhao et al. ${ }^{17}$ were also lower than the values obtained by Qiu et al. ${ }^{14}$ for the NiTi without surface treatment. Therefore, when the same substrate (NiTi) is analyzed in different electrolytes that simulate body fluids, there may be problems in interpreting the results obtained by different authors.

Shahrabi et al. ${ }^{11}$ studied bulk NiTi, polished to 1500 grit, in both Ringer's and Hank's solutions. The authors observed a higher $\mathrm{E}_{\mathrm{br}}$ in Ringer's solution $(747 \mathrm{mV})$. Furthermore, the passive region of the bulk in Ringer's solution has shifted to the right (higher current density) in comparison with Hank's solution ${ }^{11}$. Another work, by Liang and $\mathrm{Mou}^{24}$, studied the effects of different electrolytes (Ringer's, PBS and Hank's solution) on anticorrosion biometallic materials (SUS316L stainless steel, Co-Cr alloy and Ti-6Al-4V). The results indicate that the corrosion caused by the Ringer's solution is the strongest, followed by the PBS and Hank's solutions. In addition, the decrease of the $\mathrm{pH}$ of the solution significantly increased the corrosion rate and the susceptibility to localizated corrosion of SUS316L and Co-Cr. On the other hand, Ti-6Al-4V alloys exhibited stability and only a slight increase of corrosion rate with decreasing $\mathrm{pH}$.

In general, as mentioned before, studies envolving biomedical alloys already showed different electrochemical results when distincts electrolytes were used to simulated the body fluids, which indicates the important influence of the electrolyte composition. Besides, different alloys can present distint behavior in the same electrolyte. In this context, the aim of this work is to evaluate the influence of the different electrolytes used to simulate the body fluids on assessing the NiTi corrosion resistance. For this purpose, the Ringer, Hanks, HBSS and SBF solutions were chosen. Additionally a $0.9 \% \mathrm{NaCl}$ solution was used following some authors suggestions that its corrosion potential is similar to the body fluid due to its high chloride concentration $^{1,25,26}$.

\section{Experimental}

\subsection{Sample preparation}

The near-equiatomic superelastic NiTi (Ni 55.8 wt\%) alloy was used for this study. NiTi samples were cut using the Electric Discharge Machining (EDM). The test specimen dimensions were $15 \mathrm{~mm}$ x $15 \mathrm{~mm}$ x $1 \mathrm{~mm}$. All samples were polished with silicon carbide sandpaper up to the 600 grade and subsequently isolated with Araldite ${ }^{\circledR}$, defining an area of $0.91 \mathrm{~cm}^{2}$ for electrochemical tests.

\subsection{Preparation of electrolytes}

The following electrolytes were prepared according to published articles: Ringer ${ }^{27}$, Hanks ${ }^{28}, \mathrm{HBSS}^{22}$ and $\mathrm{SBF}^{29}$. A 9 g.L $\mathrm{L}^{-1}(153 . \mathrm{mmol} / \mathrm{L}) \mathrm{NaCl}(0.9 \% \mathrm{NaCl})$ distilled water solution was prepared. The ion concentration of each prepared solution is described on Table 1. For comparison purposes, the human blood plasma ion concentrations is also demonstrated on Table $1^{28}$.

The $\mathrm{pH}$ measurements were perfomed in a Sanxin PHS-3D pHmeter at $37{ }^{\circ} \mathrm{C}$ for Hanks, HBSS, SBF and Ringer solutions, and $25^{\circ} \mathrm{C}$ for $\mathrm{NaCl} 0.9 \%$ (Table 2).

\subsection{Electrochemical characterization}

Open circuit potential (OCP) measurements and potentiodynamic polarization curves were performed threefold, under an inert atmosphere, in an Autolab PGSTAT302N potenciostat/galvanostat, according to the ASTM F2129-08 standard $^{18}$. The test temperature was of $25^{\circ} \mathrm{C}(0.9 \% \mathrm{NaCl})$, with a maximum variation of $1^{\circ} \mathrm{C}$, and of $37{ }^{\circ} \mathrm{C}$ - for the other solutions, with the same variation. The $0.9 \% \mathrm{NaCl}$ solution was prepared at room temperature to reproduce the methodology described by several authors ${ }^{1,25,26}$. The OCP and potentiodynamic polarization were performed in a conventional three-electrode electrochemical cell. The working electrode was the NiTi samples, the counter electrode was a platinum wire, and the reference electrode was a satured calomel electrode (SCE). The OCP was monitored for 1 hour, the period that was necessary to stabilize the electrochemical system. The cyclic voltammetry was performed from the OCP potentials until $2 \mathrm{~V}$ in reference to the SCE with a scan rate of $1 \mathrm{mV} \cdot \mathrm{s}^{-1}$.

\subsection{Superficial characterization}

The superficial characterization was performed in polished NiTi after potenciodynamic polarization in $0.9 \% \mathrm{NaCl}$, Hanks, HBSS, Ringer and SBF solution using an scanning electron microscopy (SEM), JEOL 6060. Characterization was also made in polished NiTi without the electrochemical test for comparison purposes.

\section{Results and Discussions}

\subsection{Electrochemical characterization}

The OCP values that were obtained are shown in Figure 1. The lowest OCP value, measured at 3600 seconds $(-291 \mathrm{mV})$, which is the most active potential, was developed in HBSS solution. Considering the electrolytes studied at $37^{\circ} \mathrm{C}, \mathrm{HBSS}, \mathrm{SBF}$ and Ringer demonstrated the highest corrosion potential, which may be associated to a higher $\mathrm{Cl}^{-}$concentration in these electrolytes (Table 1). NiTi alloy is susceptible to pitting corrosion in chloride containing solutions ${ }^{30}$. Attack by $\mathrm{Cl}^{-}$in NiTi result in $\mathrm{Ni}$ being released into the solution and decrease in the local Ni concentration at the pitting sites ${ }^{31}$. The remaining Ti reacts with dissolved oxygen from the solution to form titanium oxides in the corroded area $^{31}$. The corrosion product layer expands over the entire surface and is composed of $\mathrm{TiO}_{2}, \mathrm{Ti}_{2} \mathrm{O}_{3}$, and 
Table 1. Simulated body fluids and human blood plasma ion concentrations.

\begin{tabular}{|c|c|c|c|c|c|c|c|c|}
\hline \multirow{2}{*}{ Solution } & \multicolumn{8}{|c|}{ Ion concentrations $(\mathrm{mmol} / \mathrm{L})$} \\
\hline & $\mathbf{N a}^{+}$ & $\mathbf{K}^{+}$ & $\mathbf{M g}^{+2}$ & $\mathrm{Ca}^{+2}$ & $\mathrm{Cl}^{-}$ & $\mathrm{HCO}_{3}^{-}$ & $\mathrm{HPO}_{4}^{-2}$ & $\mathrm{SO}_{4}^{-2}$ \\
\hline Hanks & 142.00 & 5.00 & 1.50 & 2.50 & 103.00 & 27.00 & 1.00 & 0.50 \\
\hline HBSS & 141.60 & 5.81 & 0.81 & 1.26 & 144.80 & 4.09 & 0.78 & 0.81 \\
\hline SBF & 142.00 & 5.00 & 1.50 & 2.50 & 147.80 & 4.20 & 1.00 & 0.50 \\
\hline Ringer & 113.60 & 1.88 & - & 1.08 & 115.30 & 2.38 & - & - \\
\hline $\mathrm{NaCl} 0.9 \%$ & 153.00 & - & - & - & 153.00 & - & - & - \\
\hline Plasma & 142.00 & 5.00 & 1.50 & 2.50 & 103.00 & 27.00 & 1.00 & 0.50 \\
\hline
\end{tabular}

Table 2. $\mathrm{pH}$ measurements of studied solutions at $37{ }^{\circ} \mathrm{C}$ (Hanks, HBSS, SBF and Ringer) and $25^{\circ} \mathrm{C}(\mathrm{NaCl} 0.9 \%)$.

\begin{tabular}{cc}
\hline Solution & pH \\
\hline Hanks & 6.82 \\
HBSS & 7.40 \\
SBF & 7.53 \\
Ringer & 5.92 \\
NaCl $0.9 \%$ & 5.50 \\
\hline
\end{tabular}

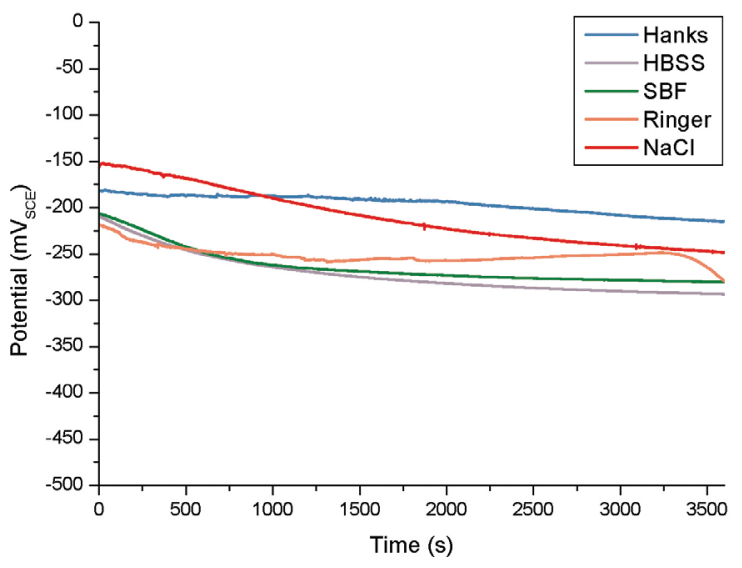

Figure 1. Open circuit potentials in different simulated body fluids at $37^{\circ} \mathrm{C}$ and in $0.9 \% \mathrm{NaCl}$ at $25^{\circ} \mathrm{C}$.

$\mathrm{TiO}$ with depleted $\mathrm{Ni}^{31}$. The change in the Ni release rate is related to the corrosion defects such as pitting pores on the NiTi specimens ${ }^{31}$. In the early immersion period, nickel ions area released gradually into the surrounding solution $^{31}$. As the immersion continues, corrosion results in the formation of pitting pores that promote nickel release, leading to a high $\mathrm{Ni}$ release rate $^{31}$. However, if the immersion time is long enough, the corrosion-induced titanium oxide layer seals the pitting pores on the NiTi surface, thereby reducing the $\mathrm{Ni}$ release rate $^{31}$. Early pitting corrosion takes place on many sites on the surface. Early corrosion process take place on surface defects initially and involves the breakdown of original thin oxide layer and $\mathrm{Ni}$-Ti bond after attack by $\mathrm{Cl}^{-}$, and this process releases $\mathrm{Ni}$ ions ${ }^{31}$. As time elapses, the pitting sites propagate and noticeable pores form on the surface ${ }^{31}$. Ni released from the bulk materials into the solution reduces the local concentration of $\mathrm{Ni}$ in the materials ${ }^{31}$. Meanwhile, the remaining Ti reacts with dissolved oxygen in the solution to form titanium oxides around the pitting sites and pores ${ }^{31}$. As the corrosion process proceeds, the titanium oxide layer grows and propagates over the entire surface of the NiTi specimen ${ }^{31}$. The pores formed during corrosion are possibly blocked by the titanium oxides formed inside the pores. As a result, a uniform and dense oxide layer is formed ${ }^{31}$. After the titanium oxide layer has formed on the entire surface of the NiTi specimen, it will serve as a passivation film to retard the corrosion process ${ }^{31}$. This susceptibility increases when the chloride concentration is higher ${ }^{30}$. In the Hanks solution, the NiTi alloy developed a less active potential $(-214 \mathrm{mV})$. Figure 2 presents the voltammograms of NiTi in different studied solutions. A slight increase in the current density occurred in the anodic potential scan, indicating a superficial oxide disruption allowing the current flow. This phenomenon of anodic dissolution in the surface indicates the beginning of the oxide layer breakdown. When the applied potential reaches $2 \mathrm{~V}$, it is reversed, and for all systems the current density of the inverse scan is higher (Figure 2). This behavior is associated to the pitting corrosion of the NiTi alloy in the studied solutions ${ }^{27}$.

In the $0.9 \% \mathrm{NaCl}$ solution, the $\mathrm{NiTi}$ samples developed current densities that were one order of magnitude lower than the others studied solutions (Figure 2) indicating that a lower temperature $\left(25^{\circ} \mathrm{C}\right)$ and the absence of other ions, such as $\mathrm{HCO}_{3}^{-1}$, can make the medium less aggressive to this alloy. However the difference in temperature, $25^{\circ} \mathrm{C}$ for the test in $0.9 \% \mathrm{NaCl}$ solution compared to $37{ }^{\circ} \mathrm{C}$ for the other electrolytes can contribute for the differences observed between $\mathrm{NaCl}$ solution and the other solutions. Few studies have investigated the effects of temperature on the corrosion resistance of nitinol, but a study in Hank's physiological solution at temperatures ranging from 10 to $80^{\circ} \mathrm{C}$ show that the ability of NiTi to repassivate is significantly reduced by an increase in temperature ${ }^{32}$. Studies using other alloys proved that a bicarbonate ion can induce pitting corrosion ${ }^{33}$. Furthermore, in a $0.9 \% \mathrm{NaCl}$ solution it is possible to observe the disruption of the passive layer at $757 \mathrm{mV}$ (Figure 2). Considering the solutions that were analyzed at $37^{\circ} \mathrm{C}$, the Hanks solution demonstrated the lowest current densities in the passive zone of the polarization curve (Figure 2). This is probably associated to $\mathrm{HCO}_{3}{ }^{-}$ion concentration in the Hanks solution (Table 1). The oxide layer was firstly ruptured, in Hanks solution, when the applied potential reached $99 \mathrm{mV}$ (current density increased from $1.55 \times 10^{-7} \mathrm{~A} / \mathrm{cm}^{2}$ to $8.72 \times 10^{-7} \mathrm{~A} / \mathrm{cm}^{2}$ ) while this value was $-78 \mathrm{mV}$ (current density increased 
from3.20 $\times 10^{-6} \mathrm{~A} / \mathrm{cm}^{2}$ to $\left.1.17 \times 10^{-5} \mathrm{~A} / \mathrm{cm}^{2}\right)$ forRinger, $-119 \mathrm{mV}($ current density increased from $2.80 \times 10^{-6} \mathrm{~A} / \mathrm{cm}^{2}$ to $1.17 \times 10^{-5} \mathrm{~A} / \mathrm{cm}^{2}$ ) for HBSS and $-148 \mathrm{mV}$ (current density increased from $2.80 \times 10^{-6} \mathrm{~A} / \mathrm{cm}^{2}$ to $\left.1.39 \times 10^{-5} \mathrm{~A} / \mathrm{cm}^{2}\right)$ for SBF. In the Hanks solution the NiTi shows a lower tendency to corrosion due to a minor passive current and a higher pitting potential, when compared to other solutions studied at $37^{\circ} \mathrm{C}$. This results demonstrated a lower corrosive tendency of $\mathrm{NiTi}$ in Hanks solution in comparison with other studied solutions. The variation in the passive zone of the polarization curve of different alloys due to the concentration of bicarbonate in the electrolyte was described by other authors ${ }^{34}$. Ions bicarbonate accelerated the cathodic reactions, promoting an oxide growth on the surface, and resulting in lower anodic current densities. Despite the curves in the other solutions having similar behavior (Figure 2), the potentials in which sudden increases of current density occurred varied. This fact suggests that it is not possible to compare the results of studies performed in different electrolytes, even if they have all been performed in simulated body fluids. A standardization of all of the parameters for corrosion tests is important to compare the different studies about the protection of NiTi surfaces. It should be mentioned that, according to some authors, it is difficult to choose an ideal solution to simulate the body fluids due to the complexity of the human physiological enviroment ${ }^{24}$. Other authors suggest that organic acids found in the blood should also be considered in the preparation of simulated body fluids ${ }^{27}$. In the present paper, the Hanks and the HBSS solutions demonstrated a good reproducibility of the results.
Considering that all samples were made of the same alloy and were submitted to the same superficial treatment, and the electrochemical tests were performed under the same parameters (temperature, sealing and scan rate), the corrosion potential variance is probably due to the different aggressiveness levels of the studied electrolytes, despite the slight difference in the $\mathrm{pH}$ among the solutions, which can influence the cathodic curves, thus affecting the corrosion potential. Nevertheless, this influence is probably not relevant, since all of the solutions are in neutral $\mathrm{pH}$ range. A study developed in Hank's physiological solution with $\mathrm{pH}$ varying from 1 to 9 showed that corrosion resistance of NiTi is not significantly affected by $\mathrm{pH}$ values $^{32}$. The Hanks solution showed the lowest aggressiveness in comparison to the other simulated body fluid solutions, which is evidenced by the less active corrosion potential and by the evolution of minor current densities. Other authors also demonstrated that the Ringer solution is stronger than the Hanks. This variation was associated to the presence of $\mathrm{Na}_{2} \mathrm{PO}_{4}$ and $\mathrm{KH}_{2} \mathrm{PO}_{4}$, which benefits the biomaterials against corrosion, in Hanks solution ${ }^{11,24}$. It is important to notice that the $\mathrm{Cl}^{-}$ions concentration is lower in the Hanks solution, in comparison to the others studied solutions. Studies indicate that the NiTi alloy is suscetible to pitting corrosion in chloride solutions, and in increasing chloride concentration, the pitting potential decreases ${ }^{30}$. In the HBSS solution the NiTi alloy developed a higher current density and more active potentials (Figure 2), which was expected due to the results obtained by the OCP (Figure 1).
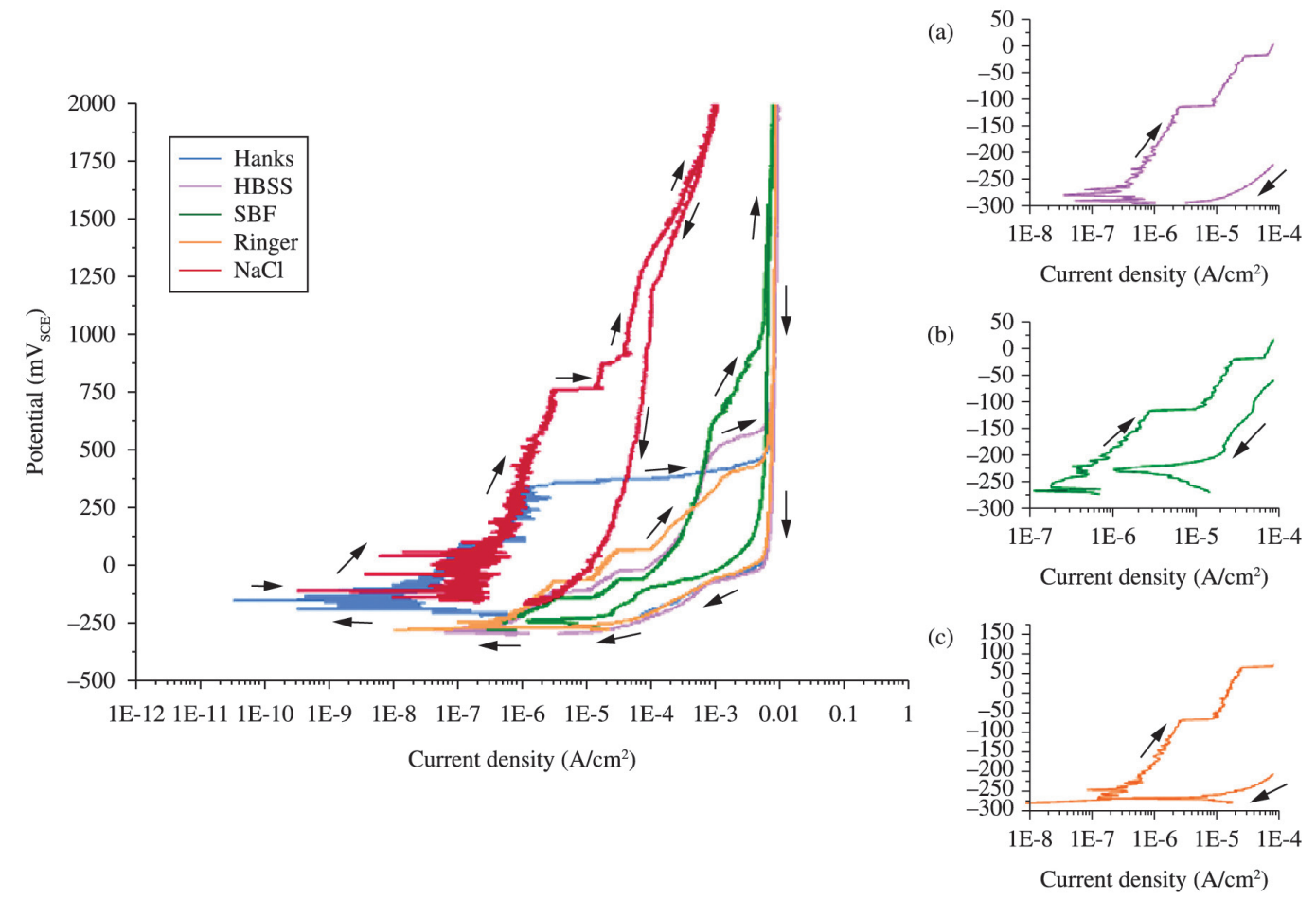

Figure 2. Potentiodynamic polarization in different simulated body fluids at $37{ }^{\circ} \mathrm{C}$ and in $0.9 \% \mathrm{NaCl}$ at $25^{\circ} \mathrm{C}$. Voltammogram detail showing the passive region of NiTi in (a) HBSS solution, (b) SBF solution and (c) Ringer solution. 


\subsection{Superficial characterization}

After the electrochemical tests, the NiTi samples were analyzed by scanning electron microscopy in order to determine the relation to the corrosion mechanism found in the electrochemical tests (Figures 3-8). Although the electrochemical results demonstrated that the NiTi alloy shows the same corrosion mechanism (pitting) in all studied



Figure 3. Mechanically polished NiTi images obtained by scanning electron microscope.

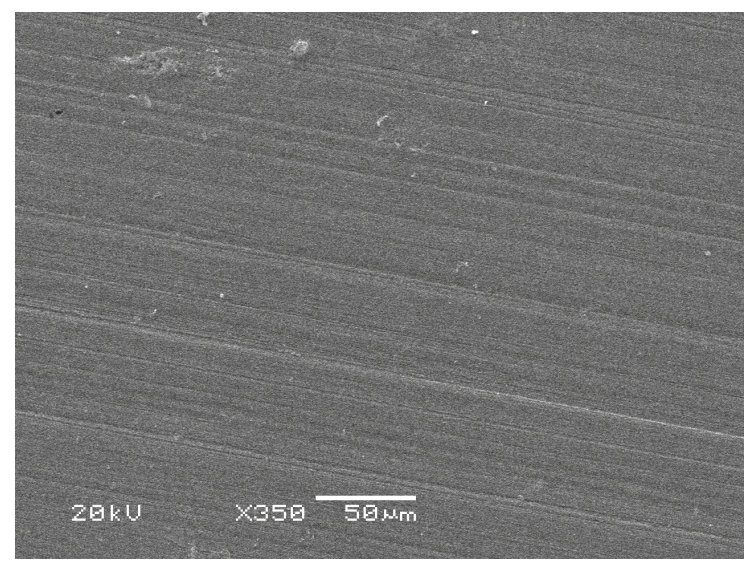

Figure 4. NiTi samples after electrochemical tests in Hanks solution, by scanning electron microscope.

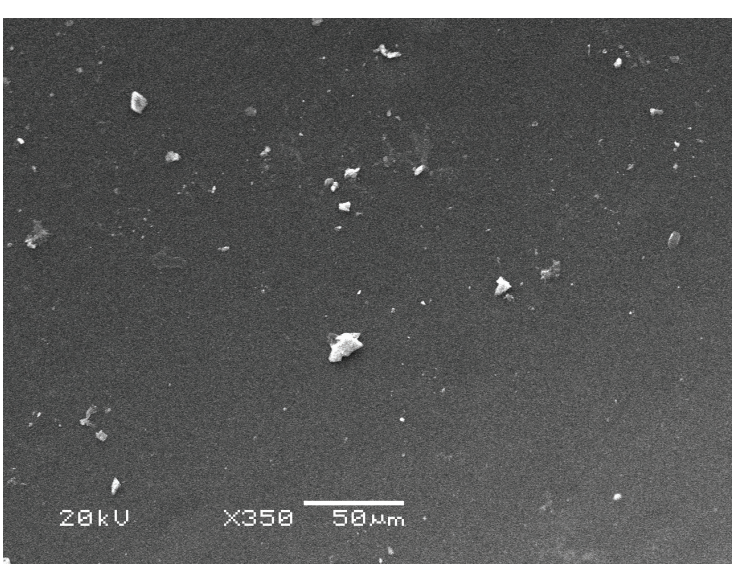

Figure 5. NiTi samples after electrochemical tests in SBF solution, by scanning electron microscope. simulated body fluids, only with the HBSS solution it was possible to notice the presence of oxidation products in the surface (Figure 6), resulting from more active potentials (Figure 2) and a higher current density; such products have been described by other authors ${ }^{35,36}$ as titanium hydroxides, which are more soluble, less protective than the oxides, and are known by an increase in the current between $\sim 1,0$ and

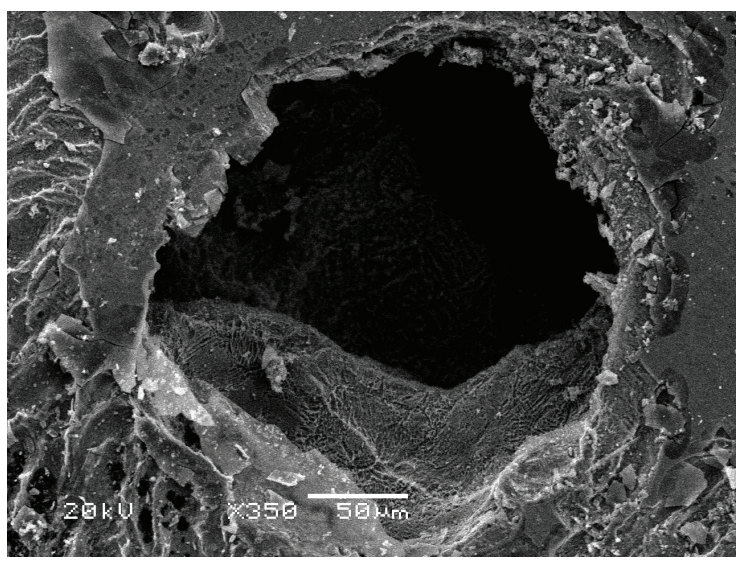

Figure 6. NiTi samples after electrochemical tests in HBSS solution, by scanning electron microscop.

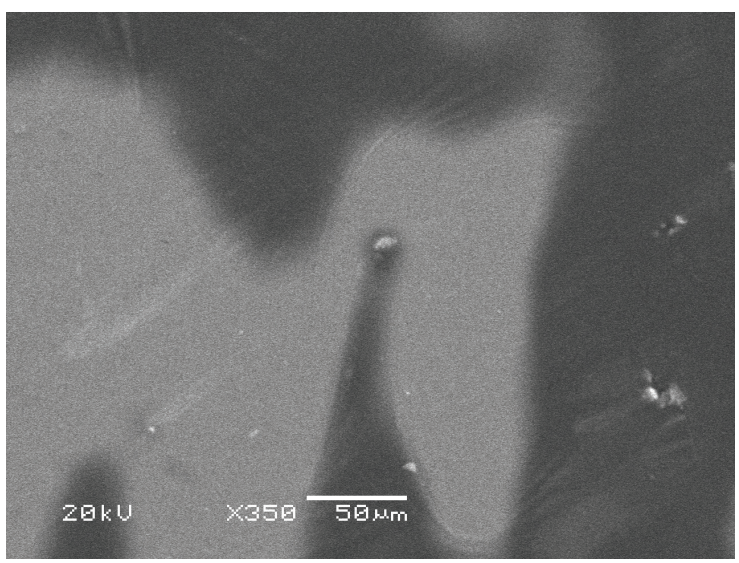

Figure 7. NiTi samples after electrochemical tests in Ringer solution, by scanning electron microscope.

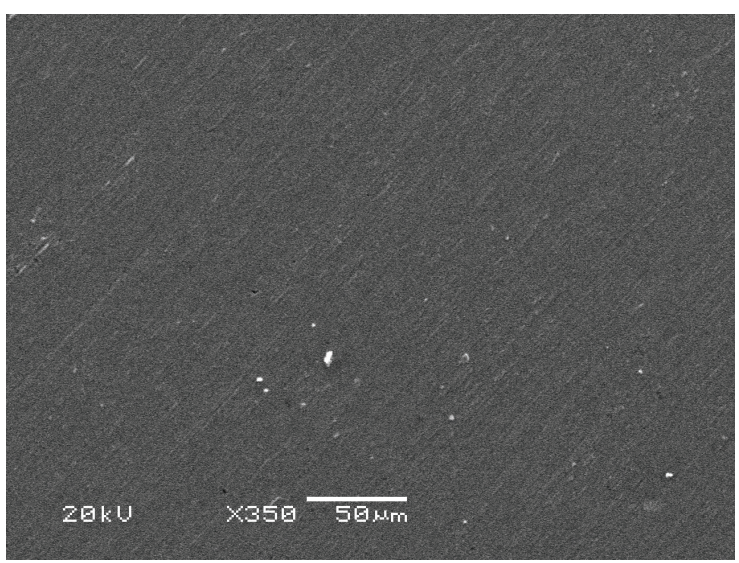

Figure 8. NiTi samples after electrochemical tests in $0.9 \% \mathrm{NaCl}$ solution, by scanning electron microscope. 
1,5 V. Other studies ${ }^{37}$ have showing pitting corrosion on $\mathrm{NiTi}$, in physiological solution, at potentials between +190 and $+280 \mathrm{mV}$ versus SCE. Oshida et al. ${ }^{38}$, evidenced NiTi low pitting potential values, and presence of numerous oscillations of anodic passive current for potentials lower than $500 \mathrm{mV}$.

\section{Conclusions}

Evaluating coatings through an appropriated method is as important as developing surface treatments for NiTi alloys. Considering that the corrosion resistance is a major issue in these alloys, it is relevant to standardize the electrochemical procedure parameters, as the electrolytes, allowing a comparison between the various coatings developed by several researchers.

\section{References}

1. Shabalovskaya SA, Rondelli GC, Undisz AL, Anderegg JW, Burleigh TD and Rettenmayr ME. The electrochemical characteristics of native Nitinol surfaces. Biomaterials. 2009; 30(22):3662-3671. http://dx.doi.org/10.1016/j. biomaterials.2009.03.034. PMid:19345407

2. McMahon RE, Ma J, Verkhoturov SV, Munoz-Pinto D, Karaman I, Rubitschek F, et al. A comparative study of the cytotoxicity and corrosion resistance of nickeltitanium and titanium-niobium shape memory alloys. Acta Biomaterialia. 2012; 8(7):2863-2870. http://dx.doi. org/10.1016/j.actbio.2012.03.034. PMid:22465573

3. Dinca VC, Soare S, Barbalat A, Dinu CZ, Moldovan A, Stoica I, et al. Nickel-titanium alloy: Cytotoxicity evaluation on microorganism culture. Applied Surface Science. 2006; 252(13):4619-4624. http://dx.doi.org/10.1016/j. apsusc.2005.07.093.

4. Wever DJ, Veldhuizen AG, Sanders MM, Schakenraad JM and van Horn JR. Cytotoxic, allergic and genotoxic activity of a nickel-titanium alloy. Biomaterials. 1997; 18(16):11151120. http://dx.doi.org/10.1016/S0142-9612(97)00041-0. PMid:9247349

5. Fili P, Lausmaa J, Musialek J and Mazanec K. Structure and surface of TiNi human implants. Biomaterials. 2001; 22(15):2131-2138. http://dx.doi.org/10.1016/S01429612(00)00404-X. PMid:11432593

6. Bernard SA, Balla VK, Davies NM, Bose S and Bandyopadhyay A. Bone cell-materials interactions and $\mathrm{Ni}$ ion release of anodized equiatomic NiTi alloy. Acta Biomaterialia. 2011; 7(4):1902-1912. http://dx.doi.org/10.1016/j. actbio.2011.01.004. PMid:21232641

7. Horiuchi Y, Horiuchi M, Hanawa T and Soma K. Effect of surface modification on the photocatalysis of Ti-Ni alloy in orthodontics. Dental Materials Journal. 2007; 26(6):924-929. http://dx.doi.org/10.4012/dmj.26.924. PMid:18203500

8. Dhage SR, Choube VD, Samuel V and Ravi V. Synthesis of nanocrystalline $\mathrm{TiO} 2$ at $100{ }^{\circ} \mathrm{C}$. Materials Letters. 2004; 58(17-18):2310-2313. http://dx.doi.org/10.1016/j. matlet.2004.02.021.

9. Vojtěch D, Novák P, Novák M, Joska L, Fabián T, Maixner $\mathrm{J}$, et al. Cyclic and isothermal oxidations of nitinol wire at
This study compared the most commonly used electrolytes to simulated body fluids: Hanks, HBSS, SBF, Ringer and $0.9 \% \mathrm{NaCl}$. Electrochemical and morphological results, show that the NiTi presents the same corrosion mechanism (pitting induced by $\mathrm{Cl}^{-}$and $\mathrm{HCO}_{3}^{-}$ions) in all studied simulated body fluids. However, the Hanks solution demonstrated less aggressiveness in comparison to other simulated body fluids, which is evidenced by its less active corrosion potential and by the development of lowest current densitie values, probably due to a lower chloride concentration. In the HBSS, SBF and Ringer solutions, the NiTi showed higher current densities and a more active potential. The Hanks and HBSS solutions presented the best reproducibility of results. Considering that the HBSS represents an extreme environment, this solution seems to be the most indicated to study the corrosion behavior of NiTi treated surfaces.

moderate temperatures. Intermetallics. 2008; 16(3):424-431. http://dx.doi.org/10.1016/j.intermet.2007.12.006.

10. Shen Y, Wang G, Chen L, Li H, Yu P, Bai M, et al. Investigation of surface endothelialization on biomedical nitinol (NiTi) alloy: Effects of surface micropatterning combined with plasma nanocoatings. Acta Biomaterialia. 2009; 5(9):35933604. http://dx.doi.org/10.1016/j.actbio.2009.05.021. PMid:19477302

11. Shahrabi T, Sanjabi S, Saebnoori E and Barber ZH. Extremely high pitting resistance of NiTi shape memory alloy thin film in simulated body fluids. Materials Letters. 2008; 62(1718):2791-2794. http://dx.doi.org/10.1016/j.matlet.2008.01.052.

12. Huan Z, Fratila-Apachitei LE, Apachitei I and Duszczyk J. Porous NiTi surfaces for biomedical applications. Applied Surface Science. 2012; 258(13):5244-5249. http://dx.doi. org/10.1016/j.apsusc.2012.02.002.

13. Liu XM, Wu SL, Chu PK, Chung CY, Chu CL, Yeung KWK, et al. Effects of water plasma immersion ion implantation on surface electrochemical behavior of NiTi shape memory alloys in simulated body fluids. Applied Surface Science. 2007; 253(6):3154-3159. http://dx.doi.org/10.1016/j. apsusc.2006.07.008.

14. Qiu D, Wang A and Yin Y. Characterization and corrosion behavior of hydroxyapatite/zirconia composite coating on NiTi fabricated by electrochemical deposition. Applied Surface Science. 2010; 257(5):1774-1778. http://dx.doi.org/10.1016/j. apsusc.2010.09.014.

15. Lifeng Z, Yan H, Dayun Y, Xiaoying L, Tingfei X, Deyuan $Z$, et al. The underlying biological mechanisms of biocompatibility differences between bare and TiN-coated NiTi alloys. Biomedical Materials (Bristol, England). 2011; 6(2):025012. http://dx.doi.org/10.1088/1748-6041/6/2/025012. PMid:21441653

16. Gupta R and Kumar A. Bioactive materials for biomedical applications using sol-gel technology. Biomedical Materials (Bristol, England). 2008; 3(3):034005. http://dx.doi. org/10.1088/1748-6041/3/3/034005. PMid:18689920

17. Zhao T, Li Y, Xiang Y, Zhao X and Zhang T. Surface characteristics, nano-indentation and corrosion behavior of $\mathrm{Nb}$ implanted NiTi alloy. Surface and Coatings Technology. 2011; 205(19):4404-4410. http://dx.doi.org/10.1016/j. surfcoat.2011.03.061. 
18. American Society for Testing and Materials - ASTM. F2129-08: Standard Test method for conducting cyclic potentiodynamic polarization measurements to determine the corrosion susceptibility of small implant devices. West Conshohocken; 2008. http://dx.doi.org/10.1520/F2129-08.

19. Liu XM, Wu SL, Chu PK, Chung CY, Chu CL, Chan YL, et al. In vitro corrosion behavior of TiN layer produced on orthopedic nickel-titanium shape memory alloy by nitrogen plasma immersion ion implantation using different frequencies. Surface and Coatings Technology. 2008; 202(11):2463-2466. http://dx.doi.org/10.1016/j.surfcoat.2007.08.017.

20. Bayat N, Sanjabi S and Barber ZH. Improvement of corrosion resistance of NiTi sputtered thin films by anodization. Applied Surface Science. 2011; 257(20):8493-8499. http://dx.doi. org/10.1016/j.apsusc.2011.05.001.

21. Shi P, Cheng FT and Man HC. Improvement in corrosion resistance of NiTi by anodization in acetic acid. Materials Letters. 2007; 61(11-12):2385-2388. http://dx.doi. org/10.1016/j.matlet.2006.09.020.

22. Chrzanowski W, Neel EAA, Armitage DA and Knowles JC. Effect of surface treatment on the bioactivity of nickel-titanium. Acta Biomaterialia. 2008; 4(6):1969-1984. http://dx.doi. org/10.1016/j.actbio.2008.05.010. PMid:18565807

23. Park HH, Park IS, Kim KS, Jeon WY, Park BK, Kim HS, et al. Bioactive and electrochemical characterization of $\mathrm{TiO} 2$ nanotubes on titanium via anodic oxidation. Electrochimica Acta. 2010; 55(20):6109-6114. http://dx.doi.org/10.1016/j. electacta.2010.05.082.

24. Liang C-h, Mou Z. Effects of different simulated fluids on anticorrosion biometallic materials. Transactions of Nonferrous Metals Society of China. 2001;11(4):579-582.

25. Flamini DO, Saugo M and Saidman SB. Electrodeposition of polypyrrole on Nitinol alloy in the presence of inhibitor ions for corrosion protection. Corrosion Science. 2014; 81:36-44. http://dx.doi.org/10.1016/j.corsci.2013.11.063.

26. Maho A, Delhalle J and Mekhalif Z. Study of the formation process and the characteristics of tantalum layers electrodeposited on Nitinol plates in the 1-butyl-1methylpyrrolidinium bis(trifluoromethylsulfonyl)imide ionic liquid. Electrochimica Acta. 2013; 89:346-358. http://dx.doi. org/10.1016/j.electacta.2012.11.026.

27. Khalil-Allafi J, Amin-Ahmadi B and Zare M. Biocompatibility and corrosion behavior of the shape memory NiTi alloy in the physiological environments simulated with body fluids for medical applications. Materials Science and Engineering C. 2010; 30(8):1112-1117. http://dx.doi.org/10.1016/j. msec.2010.06.007.
28. Siu HT and Man HC. Fabrication of bioactive titania coating on nitinol by plasma electrolytic oxidation. Applied Surface Science. 2013; 274:181-187. http://dx.doi.org/10.1016/j. apsusc.2013.03.008.

29. Kokubo $\mathrm{T}$ and Takadama H. How useful is SBF in predicting in vivo bone bioactivity? Biomaterials. 2006; 27(15):29072915. http://dx.doi.org/10.1016/j.biomaterials.2006.01.017. PMid:16448693

30. Li X, Wang J, Han EH and Ke W. Influence of fluoride and chloride on corrosion behavior of NiTi orthodontic wires. Acta Biomaterialia. 2007; 3(5):807-815. http://dx.doi.org/10.1016/j. actbio.2007.02.002. PMid:17467350

31. Hu T, Chu C, Xin Y, Wu S, Yeung KWK and Chu PK. Corrosion products and mechanism on NiTi shape memory alloy in physiological environment. Journal of Materials Research. 2010; 25(02):350-358. http://dx.doi.org/10.1557/ JMR.2010.0051.

32. Trépanier $\mathrm{C}$ and Pelton $\mathrm{AR}$. Effect of temperature and $\mathrm{pH}$ on the corrosion resistance of Nitinol. In: Medical Device Materials II: Proceedings from the Materials \& Processes for Medical Devices Conference 2004; 2004. St. Paul Minnesota: ASM International; 2005. p. 392.

33. Han J, Zhang J and Carey JW. Effect of bicarbonate on corrosion of carbon steel in $\mathrm{CO} 2$ saturated brines. International Journal of Greenhouse Gas Control. 2011; 5(6):1680-1683. http://dx.doi.org/10.1016/j.ijggc.2011.08.003.

34. Torres-Islas A, Gonzalez-Rodriguez JG, Uruchurtu J and Serna S. Stress corrosion cracking study of microalloyed pipeline steels in dilute $\mathrm{NaHCO} 3$ solutions. Corrosion Science. 2008; 50(10):2831-2839. http://dx.doi.org/10.1016/j. corsci.2008.07.007.

35. Milošv I, Strehblow H-H, Navinšek B and Metikoš-Huković M. Electrochemical and thermal oxidation of TiN coatings studied by XPS. Surface and Interface Analysis. 1995; 23(78):529-539. http://dx.doi.org/10.1002/sia.740230713.

36. Tomashov ND, Chukalovskaya TV, Myedova LL and Yegorov FF. Corrosion and anodic behaviour of carbide, nitride and boride of titanium in sulphuric and phosphoric acids. Zaschyta Myetallov. 1985;5:682-688.

37. Rondelli G. Corrosion resistance tests on NiTi shape memory alloy. Biomaterials. 1996; 17(20):2003-2008. http://dx.doi. org/10.1016/0142-9612(95)00352-5. PMid:8894095

38. Oshida Y, Sachdeva R, Miyazaki S and Fukuyo S. Biological and Chemical Evaluation of TiNi Alloys. Materials Science Forum. 1990; 56-58:705-710. http://dx.doi.org/10.4028/www. scientific.net/MSF.56-58.705. 